\title{
Research on Lean Cloud Process Management
}

\author{
Ziqin Ma, a , Pengfei Zhao, ${ }^{1, \mathrm{~b}}$, Yanan Chen ${ }^{1, \mathrm{~b}}$, Tong Wang ${ }^{1, \mathrm{~b}}$, \\ Chen Peng ${ }^{1, \mathrm{~b}}$, Li Sun ${ }^{1, \mathrm{a}}$, Qiang Cheng ${ }^{1,2, \mathrm{c}}$, Jiang Wei ${ }^{2, \mathrm{c}}$ \\ ${ }^{1}$ School of Mechanical Engineering, Dalian Jiaotong University, Dalian, \\ CHINA \\ ${ }^{2}$ Dalian Locomotive and Rolling Stock Co., Ltd, CNR GROUP, Dalian, \\ CHINA \\ amaziqin@djtu.edu.cn, b1032416818@qq.com, 4442698561@qq.com
}

\begin{abstract}
As a kind of manufacturing technology, Lean manufacturing can not only greatly reduce the switch time, idle time, but also can improve the product quality, reduce inventory, shorten the product development cycle of design. Process management is the basis of enterprising management and the important guarantee of improving the quality of products stably and improving production efficiency. Now the modern process management combines with Lean manufacturing to realize Lean process management. At the same time, with the rapid development of the Internet applications, the "cloud" has become a hot in the field of information, it has changed the way obtain information, share resources and communicate with each other. This paper will describe the cloud technology in the application of Lean process management.
\end{abstract}

Keywords: Lean Manufacturing; Process Management; Cloud Technology

\section{Introduction}

With the development of manufacturing, Lean thinking has become more and more widely applied in production in enterprise, and made some good results. But process management is always our weaknesses, now we combine Lean thinking with Process management and make full use of cloud, namely Cloud Lean Process Management, and it will be an inevitable trend of modern manufacturing.

\section{Summary of Lean Manufacturing}

Lean production [1] [2] can be defined as an adaptation of mass production in which workers and work cells are made more flexible and efficient by adopting methods that reduce waste in all forms. Lean production is based on five principles:

Define the Value. The core of Lean thinking is to eliminate waste, and the primary issue is to identify waste. Define value is the first step on the Lean thinking, which is the most important step. Lean thinking request producers 
standing in customer's point of view, to design products that meet the needs of customers, and even to define the value of the product by the customer. To meet customer demand is the basis of Lean thinking definition value.

Identify the Value Stream. The meaning of identify the value stream is to find the meaning of value creation process, namely the value chain. "Value Stream Analysis" is the most important method to identify the value stream, the product creation process by drawing all activities can clearly find a complete value chain. The purpose of identify the value stream is to identify waste in the process of value creation.

The Flow of the Value. Recognition of the value stream, we can find value in the conversion of waste between the various enterprises. But in the enterprise internal also have a lot of waste. Value will be working along the value creation, and do not create value activities (such as downtime, rework and repair) is bound to the value stream flow intermittent. Through the way of value flow, Lean thinking completed the process of identifying the internal waste.

Demand Pull. Demand-pull means: the organization of production according to customer's demand, enabling customers to obtain the desired value at a certain time. Under the principle of "pull" production and demand correspond directly, eliminating the excessive and premature investment, greatly reducing waste and inventory pressures, compressed production time.

Continuous Improvement. Some waste under the existing level of technology can be completely eliminated, but a waste of existing technology and production conditions can not be eliminated, it is necessary to use the first five principles of Lean thinking, namely continuous improvement, and eliminate the waste that exists in the enterprise eventually completely.

\section{Stages of Product Development under Lean Manufacturing}

Analysis of the Process of Product Development before the Value Stream. Value stream refers to from raw materials to finished products, and give it gives all the activities of value. This process includes: the task of the whole production process which is detailed design and engineering, the task of the whole process of information management which is from taking orders to the detailed schedule and the task of the material transformation of the user which is from raw material into the final product. We want to create a necessary value stream map of every action which can identify design, ordering, and to manufacture a specific product, including: There are many specific steps to create value ; There are many inevitably other steps which do not create value under the condition of existing technology and production ; There are many the steps which do not create value and can remove immediately. Through the production process of the inspection, you will find that there is so much waste in our original used mode of production, thus we can eliminate the steps that can not create value.

Lean Design Cost Management before Product Development.The Lean cost management [5]should focus on the product development stage, and it is the key of enterprise success or failure in competition. Foreign data show: $80 \%$ of products are formed in the product design stage on the cost cause. So cost planning work must 
run through the whole process of product development. In general should follow the following procedures: We must determine the new product development tasks at the same time the new product development costs. Target cost is depending on the market forecast sales price and long-term business plan target profit price subtraction formula; According to the product structure, target cost implement the total cost of the product and parts; Each phase of product development must forecast and analysis the level that target cost reached actually. According to the problems found in comparative analysis and through the value engineering and value analysis method, we need research and use cost reduction measures to promise not to break through the target cost.

\section{Stages of Product Process under Lean Manufacturing}

Process Management of Pulling the Product Production[3]. Traditional mass production usually promote push production, each production workshop is scheduled to produce parts, the actual completion feedback to the production planning department, and the finished parts send to next process or downstream production workshop and ignore next procedure and downstream production workshop whether to need them at that time. In this way, the logistics and information flow is basically separate; the whole process is equal to push from the front to the back. While the pull production in Lean production is determined by demand information of the market to assembly, then product assembly pull parts processing. Each working procedure and each process according to the need require and order forward, upstream workshop, and the upstream process, workshop production in accordance with these instructions product completely. Logistics and information flow is together, the whole process is equivalent to pull forward from the back.

Just-in-time Production Process Management in the Production process. It requires that the products flow from Gross-PUI into finished products of the whole manufacturing process, parts are always does not stop, do not backlog, do not go beyond, produced according to the flow of the beat one by one. The specific process includes: Immediately after each working procedure processing a part into the next process; The number of products between processes does not exceed the number of the clamping process before; The movement of parts is uninterrupted, not beyond, and do not fall to the ground; Production process and inspection process and the transportation process are an organic whole; Only qualified products are allowed to flow to the next working procedure.

Board Management Process in the Production Process. In Lean production [1], board is a way to adjust and control management in the necessary time to produce the necessary products. It is usual a card, there are parts model, pickup location, location, quantity, delivery equipment model and filling in the information, production as a pickup, transport and production instruction. In Lean production board production process has the following six processes: Process B received production board; By retrieving the board and empty container I, Process B go to process A pick it up; Process B get off container II which is filled with required parts from production board, and take the goods board, after checking the 
production process of A production board and put it into the collection box board, pickup board on A container II; Process B take away box II, and put the container I in the position of the container II; Process B start production according to the requirements of the production board; Process A receive production board and pick the previous procedure up .

\section{Stages of Process Continuous Improvement under Lean Manufacturing}

Continuous improvement is the power of Lean production system, and without improvement, there is not Lean production. Lean process continuous improvement has the following aspects:

Minimize Waste. Lean production theory think that all can't improve value is waste, the waste forms can be listed as follows: production of defective parts, production of more than the number of items needed, unnecessary inventories, unnecessary processing steps, unnecessary movement of people, unnecessary transport of materials, and workers waiting;

There is room for improvement and improve from local to whole forever. The structure of the operation, quality, production and the way to management continuously improve forever;

Save manpower and material resources;

Pay attention to participation and constant insist on. In this way Japan's Toyota achieved remarkable results in improving quality, reducing cost, eliminating waste and other activities.

\section{Cloud Technology is in the Application of Lean Process Management}

The Technical Basis of Lean Cloud Process. Cloud computing[4] is the development of Grid computing, parallel computing and distributed computing, is a new business computing mode. And with the help of a SaaS, PaaS, IaaS and other advanced business model, it distributes the powerful computing capacity to the end user. SaaS provides program to the user with the approval of service and charge according to user requirements. PaaS provides the development environment, the environment that application is running and the database environment as a service to operators, then operators develop program and provide it the user via the Internet. IaaS puts computing and storage resources which are largely distributed in computers and storage devices together into a virtual resource pool, then as a service provide to the users.

Construct of the Cloud Lean Process Management Model. According to the understanding of Lean manufacturing and modern management theory, as well as to the understanding and use of cloud computing related content. In this paper, the schematic about structure of Cloud Lean Process Management is put forward (as shown in Fig. 1).The schematic describes the formation process about the Cloud Lean Process Management system framework and its operation principle. The 
schematic diagram is mainly consists of the infrastructure layer, data layer, platform management layer and application layer.

The Infrastructure Layer (Infrastructure as a service) .The infrastructure layer provides the material base for Cloud Lean Process Management system for resource virtualization. The infrastructure layer provides virtual hardware resources, such as the virtual host, storage, network, database management, and other resources.

The Data Layer.Lean process management cloud is the platform which is virtual resource services, releasing and dealing with customer demand and analysis of and Lean process management, is the core part of the Lean process management cloud structure model.

The Platform Management Layer (Platform as a service).The platform management layer need operate, manage, monitor and maintain resources, and is mainly the related service which is encapsulation and distributed computing.

The Application Layer (Software as a service) .The application layer is the final part of the structure of Cloud Lean Process Management model, and it provides Lean manufacturing process management and service application for Lean process management requirements of related or enterprises. Users can visit interface through searching client access in a variety of devices.

\section{The Running Principle of the Cloud Lean Process Management Model}

Cloud Lean Process Management works as shown in Fig. 2. First of all, it encapsulates all kinds of resources and the ability of Lean process management process management into cloud services, this process that can be called a Lean process management resources "access". According to different types of resources and capabilities, the cloud service gathered to the Cloud Lean Process Management. Cloud Lean Process Management is the main carrier of cloud services and provides various services according to the demand of Lean process management, and this process of providing application services is known as "output". In the whole process management system operation process, cloud computing plays the role of the core supporting. 


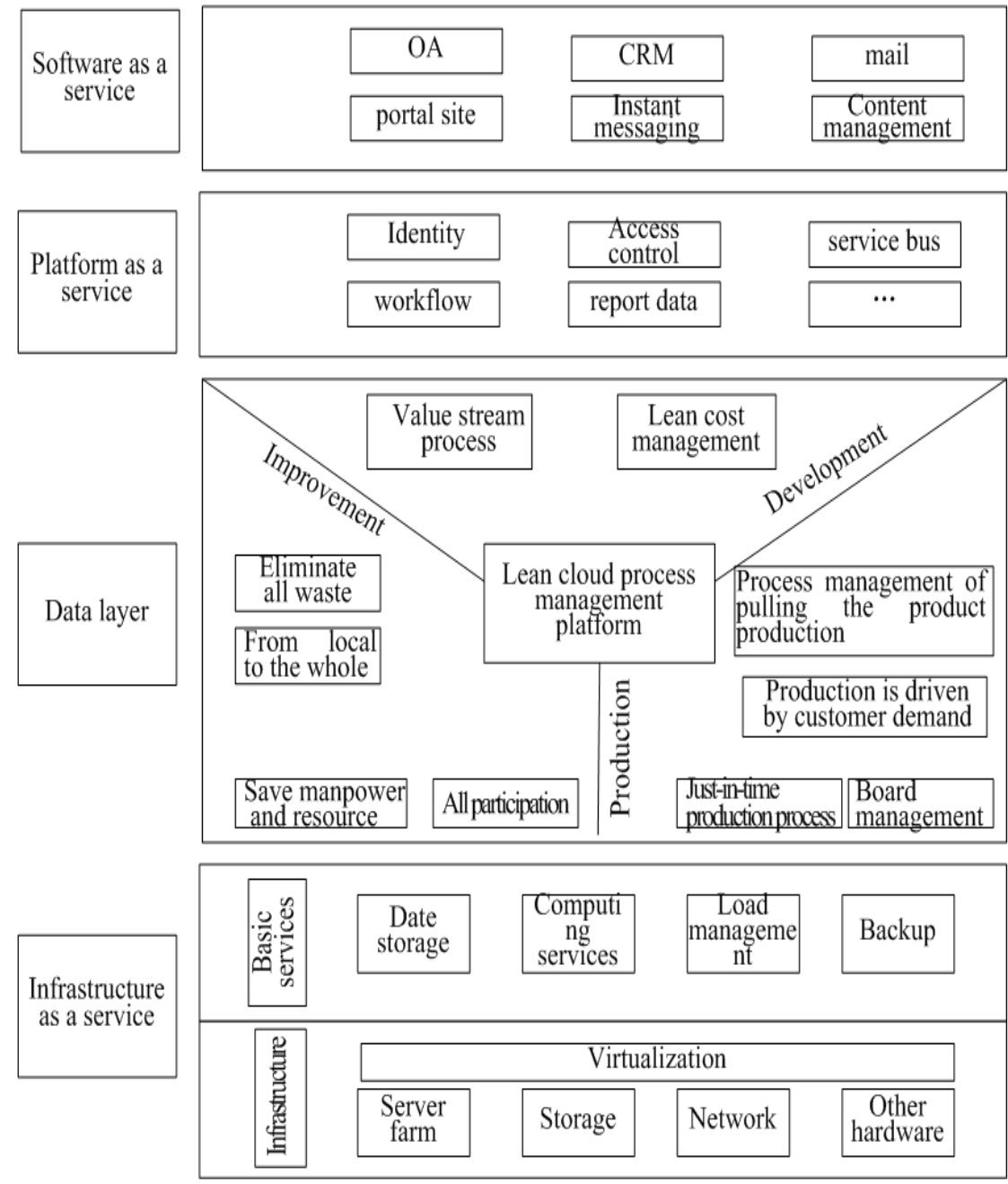

Fig. 1 the schematic about structure of Cloud Lean Process Management 


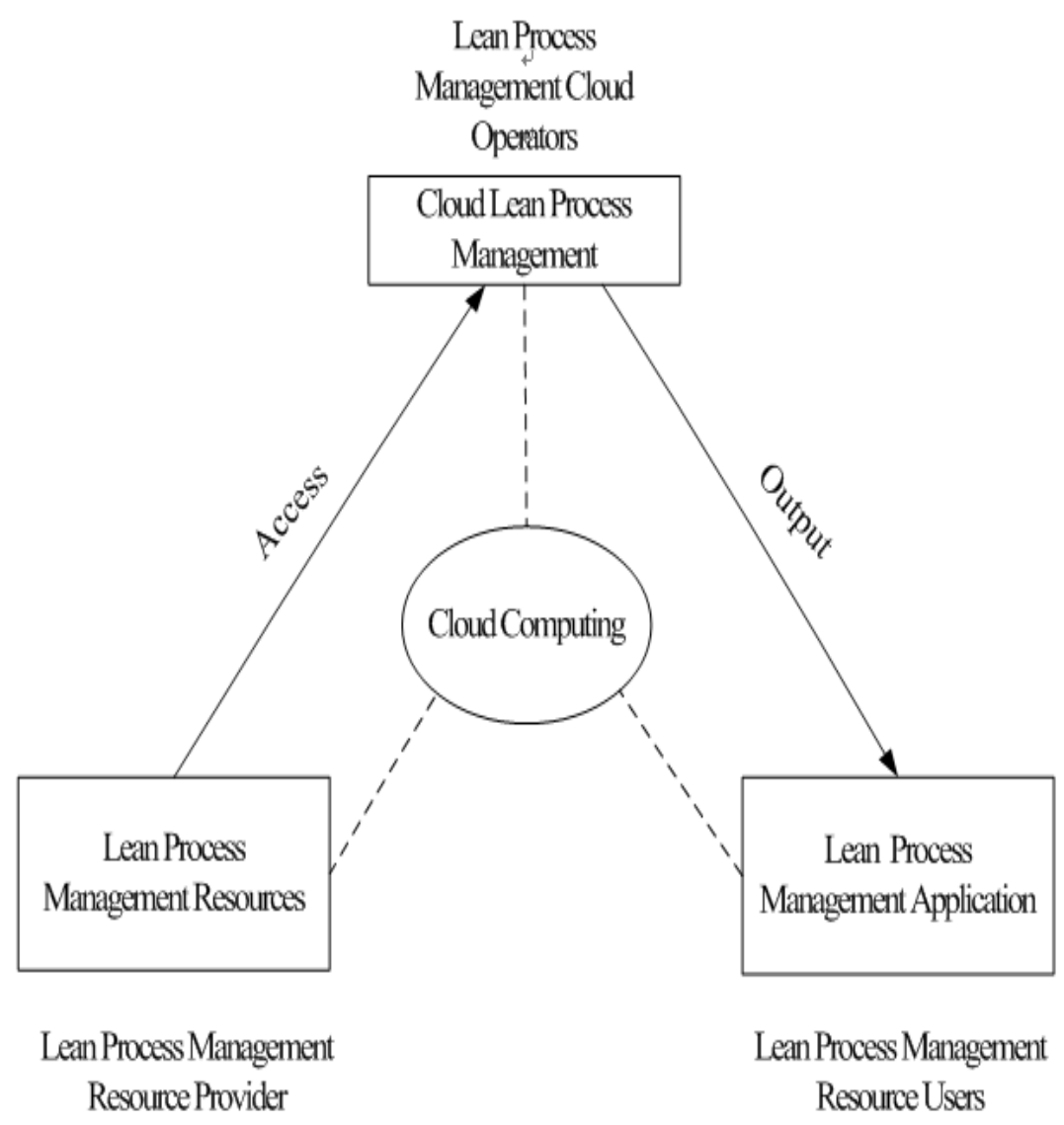

Fig. 2 The principle diagram of the Lean process management operation

\section{Conclusion}

Through cloud technology combining with Lean process management technology, it not only makes the existing product production process optimize, and makes modern process management technology Lean, but also can greatly reduce business operating costs and make full use of the resources, including the price expensive servers and network devices. So it is important significance that the cloud process applies to the modern manufacturing in the future.

\section{References}

[1] James P. Womack, Daniel T. Jones. Lean Thinking [M]. China Machine Press, 2008. (In Chinese)

[2] Freddy Balle, Michael Balle Gold [M]. China Machine Press, 2008. (In 
Chinese)

[3] Xiulun Wang. Modern Process Management Techniques [M]. China Railway Publishing House, 2004. (In Chinese)

[4] Bohu Li, Lin Zhang, Xudong Chai. Overview Of Cloud Manufacturing [M]. People's Posts And Telecommunications Publishing House, 2010. (In Chinese)

[5] Lei Cao. Agile Manufacturing And Under The Lean Production Art Planning And Management[J]. Machinery Manufacturing Research, 2009. (In Chinese) 